\title{
DAMPAK CUACA EKSTRIM PERIODE TAHUN 2016 - 2018 TERHADAP KAWASAN KONSERVASI PENYU DI SEPANJANG PESISIR SELATAN JAWA TIMUR
}

\author{
Dhira K. Saputra ${ }^{a, b, *}$, Arief Darmawan ${ }^{a, b}$, Sulastri Arsad \\ ${ }^{a}$ Fakultas Perikanan dan Ilmu Kelautan, Universitas Brawijaya, Jl. Veteran, Malang, Indonesia \\ ${ }^{\mathrm{b}}$ CORECT RG, FPIK Universitas Brawijaya, Ruang $501 \mathrm{Gd}$. Utama FPIK, Jl. Veteran, Malang, Indonesia \\ *Korespondensi penulis: saputra.dhira@ub.ac.id
}

\begin{abstract}
Abstrak
Kawasan pesisir Jawa Timur memiliki beberapa lokasi pendaratan dan peneluran penyu, akan tetapi pada saat ini belum terdapat data komprehensif yang menggambarkan kondisi dan sensitivitas kawasan tersebut terhadap ancaman perubahan iklim. Fenomena cuaca ekstrem di Samudera Hindia Timur pada kurun waktu 2016 - 2018 diduga memberikan dampak terhadap pantai peneluran penyu di pesisir Jawa Timur. Penelitian ini dilakukan untuk mengidentifikasi kondisi fisik dan pengelolaan pada 6 lokasi utama peneluran penyu di pesisir Jawa Timur. Taman Nasional Alas Purwo dan Taman Nasional Meru Betiri merupakan kawasan konservasi penyu yang dikelola oleh pemerintah, sedangkan lokasi lainnya merupakan lokasi peneluran penyu yang dikonservasi oleh kelompok masyarakat, diantaranya Pantai Taman Ria (Pacitan), Pantai Kili-Kili (Trenggalek), Pantai Pathuk Gebang (Tulungagung) dan Pantai Bajulmati (Malang). Kegiatan observasi lapangan dilaksanakan pada Tahun 2017 dan 2018. Variabel pengamatan meliputi perubahan fisik pantai akibat cuaca ekstrem, sementara analisis komponen eksposur dan sensitivitas habitat didapatkan dari pengukuran variabel temperatur substrat, serta event siklon dan anomali SPL. Hasil penelitian menunjukkan cuaca ekstrem berupa gelombang tinggi dan banjir pasang yang menyebabkan adanya fitur abrasi dan pergeseran lokasi peneluran pada pantai pendaratan penyu. Curah hujan yang tinggi pada musim peneluran menyebabkan suhu substrat berada pada rentang bawah pivot $\left(25-28^{\circ} \mathrm{C}\right)$ dengan kelembaban bervariasi. Walaupun begitu, belum terdapat bentuk manajemen adaptif terhadap perubahan iklim pada seluruh area konservasi penyu di Jawa Timur.
\end{abstract}

Kata kunci: Sensitivitas habitat, IOD, Manajemen adaptif, Resiliensi pesisir

\begin{abstract}
The southern coast of East Java provides favorable conditions of turtle conservation areas which still lacking a comprehensive database. Extreme climate events characterized by high waves and tidal floods during the period 2016 - 2018 is suspected to have an impact on the beaches alongside southern coast of Java Island. This research aimed to observe the impact of temperature anomaly and wave attack on sea turtle nesting sites located in the southern coast of East Java. A set of visual observations have been conducted in 4 community-based sea turtle conservation areas included Taman Ria Beach (District of Pacitan), Taman Kili-Kili Beach (Trenggalek), Pathuk Gebang Beach (Tulungagung), Bajulmati Beach (Malang), and 2 sea turtle conservations managed by National Park (TN Meru Betiri and TN Alas Purwo). Field sampling was collected during the early turtle nesting season in 2017 and 2018. Variables observed consist of shoreline change during climate events, substrate temperature and moisture, SST anomaly and turtle nesting data. Result shows the high rainfall affected substrate temperature below the pivotal $(25-28 \circ \mathrm{C})$ with varying soil moisture. Wave attack caused abrasion features and narrowing of the supratidal area on some parts of the beaches, which resulted on shifting of sea turtle nesting Ares. However, there is still no adaptive management plan for climate change in turtle conservation areas in the southern coast of East Java.
\end{abstract}

Keywords: Adaptive management, Coastal resilience, IOD, Sea level rise, Sea turtle

\section{PENDAHULUAN}

Penyu laut, merupakan reptil laut purba yang diproteksi secara global. IUCN meletakkan beberapa spesies penyu pada appendix I CITES, mengindikasikan status kerentanan tinggi dan perlindungan spesies yang maksimal. Indonesia merupakan salah satu negara yang meratifikasi kebijakan konservasi IUCN, sehingga memiliki aturan konservasi pada spesies maupun area pendaratan penyu. 
Pantai selatan Jawa Timur merupakan kawasan yang berbatasan dengan Samudera Hindia. Ciri khas dari kawasan ini adalah relief topografi yang kasar, akses yang sulit dan substrat pasir. Memanjang sejauh $616 \mathrm{~kg}$, dari formasi karst Gunung Sewu di Pacitan, sampai dengan Semenanjung Blambangan di Banyuwangi yang merupakan ujung timur dari pesisir selatan Jawa, terdapat pantai alami, berpasir dan memiliki area supratidal luas, sebagai lokasi favorit penyu untuk mendarat dan meletakkan telurnya. Beberapa dekade yang lalu, keberadaan penyu yang mendarat dan bertelur dapat dijumpai pada banyak area pantai berpasir di pesisir selatan Jawa Timur [1].

Seiring dengan perkembangan tata guna lahan pantai dan kemudahan akses jalan langsung menuju pantai, yang menyebabkan banyaknya kunjungan ke pantai wisata di pesisir selatan, maka jumlah lokasi dan jumlah penyu yang mendarat mengalami penurunan. Selain itu, kegiatan perburuan penyu dan aktivitas nelayan juga berdampak langsung terhadap penurunan jumlah penyu yang mendarat. Sayang sekali tidak ada data empiris mengenai hal ini, karena sumber informasi mengenai penyu di pesisir selatan Jawa Timur pada umumnya berasal dari masyarakat yang tinggal di wilayah pesisir.

Di sisi lain, sepanjang tahun 2015 - 2018, terdapat event anomali iklim di sepanjang pesisir Samudera Hindia bagian timur, dan tentunya berdampak juga terhadap area pendaratan penyu di pesisir selatan Jawa Timur. Beberapa publikasi telah menggambarkan adanya perubahan tinggi muka air laut [2] dan faktor yang mentrigger perubahan kondisi atmosferis dan oseanografi di pesisir Samudera Hindia bagian timur [2]. Sementara, untuk penelitian skala lokal terkait kondisi penyu di pesisir selatan Jawa Timur terkait cuaca ekstrem masih belum ada.

Sampai dengan saat ini masih ditemukan beberapa lokasi yang menjadi habitat favorit penyu untuk mendarat. Beberapa lokasi utama diantaranya adalah Pantai Taman Ria di Pacitan, Pantai Taman Kili-Kili di Trenggalek, Pantai Pathuk Gebang di Tulungagung, Pantai Bajulmati di Malang, Pantai Sukamade di Taman Nasional Meru Betiri, Banyuwangi dan Pantai Ngagelan Taman Nasional Alas Purwo, Banyuwangi. Kedua Taman Nasional berada di bawah pengelolaan pemerintah, melalui Balai Taman Nasional yang bernaung di bawah Kementerian Lingkungan Hidup dan Kehutanan.

Sementara itu, Pantai Taman Ria dan Pantai Taman Kili-Kili merupakan kawasan konservasi di luar Taman Nasional, yang dikelola oleh masyarakat lokal secara swadaya. Sejauh ini, belum tersedia data yang baik terkait dinamika yang terjadi pada fisik pantai peneluran penyu, maupun kondisi penyu yang mendarat. Penelitian mengenai dinamika kondisi fisik pantai peneluran penyu dan kesiapan pengelolaan terkait adaptasi perubahan iklim di area konservasi penyu pesisir selatan Jawa Timur dapat dijadikan baseline untuk pengambilan data temporal maupun perbaikan pengelolaan kawasan konservasi penyu terkait dengan ancaman perubahan iklim.

\section{MATERI DAN METODE}

Sebanyak 6 (enam) lokasi utama pendaratan penyu di pesisir selatan Jawa Timur dipilih sebagai lokasi sampling, terdiri dari dua Taman Nasional di Banyuwangi (TN Meru Betiri dan TN Alas Purwo) dilengkapi dengan empat kawasan pendaratan utama penyu yang dikelola oleh masyarakat konservasi (Pantai Taman Ria Pacitan, Pantai Taman Kili-Kili Trenggalek, Pantai Pathuk Gebang Tulungagung dan Pantai Bajulmati Malang.

Kegiatan survei lapangan dilaksanakan pada Bulan Agustus Tahun 2017, serta Juli awal September 2018, meliputi survei untuk geomorfologi pantai dan pendataan Variabel yang digunakan dalam penelitian adalah sebagai berikut:

1. Identifikasi jenis penyu, jumlah telur dan jumlah indukan yang mendarat

2. Panjang pantai didapatkan melalui trekking lapangan

3. Pengukuran lebar supratidal sebagai area favorit peneluran penyu dilakukan dengan tracking garis pantai pada garis batas swash zone sampai dengan dune foot atau batas vegetasi, menggunakan roll meter

4. Pembuatan profil kemiringan dilakukan dengan cara manual, menggunakan Abney Level dan Waterpass digital Topcon

5. Karakteristik sedimen meliputi temperatur dan kelembaban substrat yang diukur secara in situ dengan menggunakan termometer substrat, sedangkan analisis granulometri dilakukan di Laboratorium untuk mendapatkan klasifikasi sedimen berdasarkan skala Wentworth

6. Data dinamika iklim oseanik secara temporal didapatkan melalui database iklim yang disediakan oleh NASA dan BMKG

7. Analisis perubahan garis pantai akibat cuaca ekstrem dianalisis dengan menggunakan Citra Satelit Landsat 8 dan Sentinel 2A, 
dilengkapi dengan dokumentasi kondisi eksisting di lapangan

8. Terakhir, informasi untuk pengelolaan didapatkan melalui wawancara dengan pengelola, untuk mengetahui persepsi pengelola mengenai perubahan iklim dan upaya adaptif yang dilakukan untuk mengantisipasi dampak perubahan iklim terhadap lokasi peneluran

Penilaian kerentanan habitat terhadap pengaruh iklim telah dilakukan oleh [3], dengan variabel meliputi Eksposur, Sensitivitas dan
Kemampuan Adaptif. Beberapa variabel yang digunakan diantaranya suhu substrat, kenaikan muka air laut, dan aktivitas siklon. Ketiadaan basis data temporal di pantai selatan Jawa Timur membatasi penilaian untuk analisis kerentanan pantai pendaratan penyu. Penelitian ini hanya mengkuaintifikasi variabel eksposur dan sensitivitas yang terjadi selama penelitian berlangsung (2016 - 2018), sehingga dapat dijadikan basis data dasar untuk penelitian analisis kerentanan habitat penyu pada penelitian berikutnya.

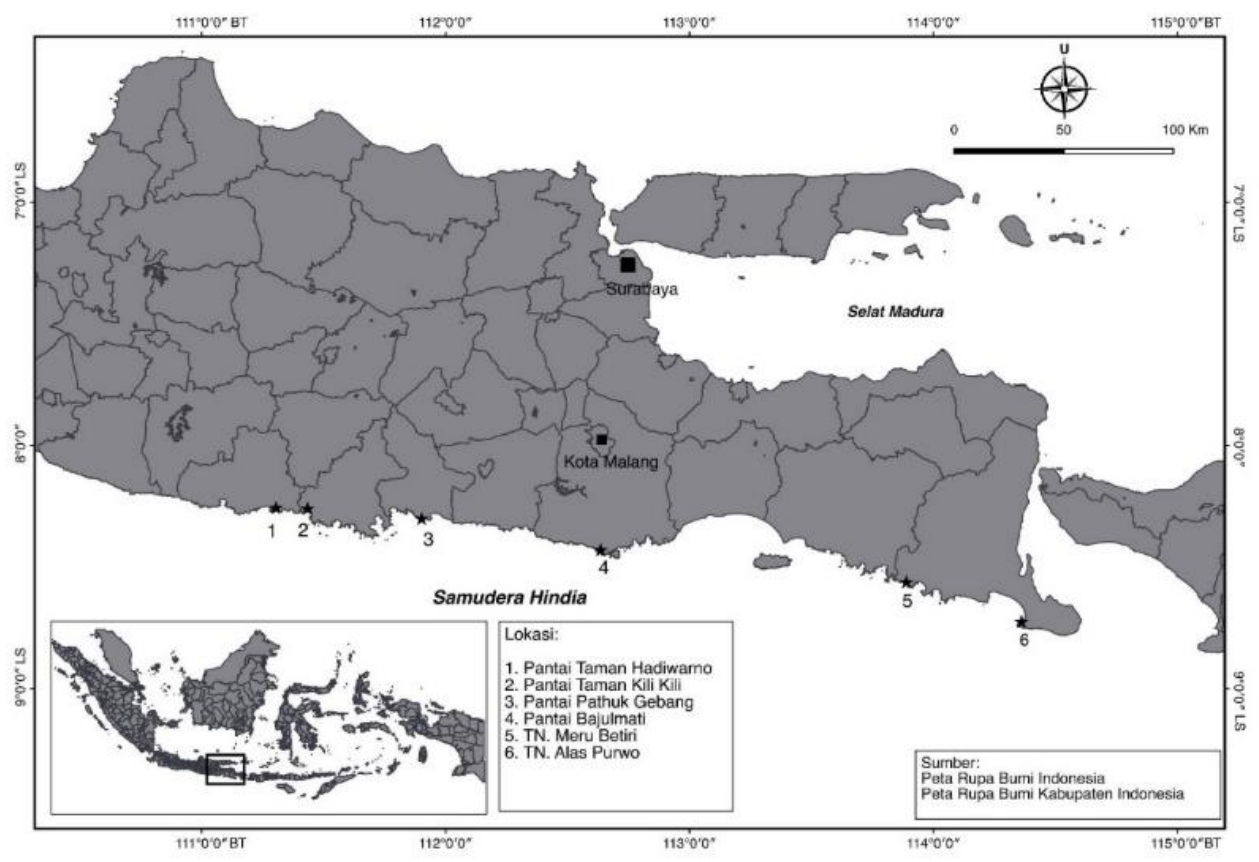

Gambar 1. Lokasi pengambilan data di pesisir selatan Jawa Timur

\section{HASIL DAN PEMBAHASAN}

\section{Kondisi Fisik pantai pendaratan penyu}

Pantai selatan Jawa Timur masih memiliki fitur pantai berpasir dengan area supratidal yang luas, serta berbatasan langsung dengan Samudera Hindia. Menurut informasi dari masyarakat, pada awalnya penyu dijumpai mendarat pada hampir setiap pantai, akan tetapi, seiring dengan perkembangan pengelolaan pesisir sebagai tujuan wisata dan maraknya perburuan penyu, pada saat ini hanya terdapat beberapa pantai yang menjadi area pendaratan utama penyu di pesisir selatan Jawa Timur. Jenis penyu yang mendominasi pantai pendaratan diantaranya adalah penyu hijau (C. mydas) di Pantai Sukamade -Taman Nasional Meru Betiri, Pantai Bajulmati dan Pantai Pathuk Gebang, penyu lekang (L. olivacea) mendominasi area pendaratan Pantai Grajagan -Taman Nasional Alas Purwo, Pantai Taman Kili-Kili dan Pantai Taman Ria. Selain itu, terdapat laporan pendaratan penyu sisik (E. imbricata) dan penyu belimbing (D. coriacea) pada Pantai Taman Kili Kili maupun Pantai Sukamade. Karakteristik fisik pantai peneluran disajikan pada Tabel 1. 


\begin{tabular}{|c|c|c|c|c|c|c|}
\hline \multirow{2}{*}{$\begin{array}{l}\text { Wilayah Adm. } \\
\text { Nama Pantai }\end{array}$} & \multirow{2}{*}{$\begin{array}{l}\text { Pacitan } \\
\text { Taman } \\
\text { Ria (TR) }\end{array}$} & \multirow{2}{*}{$\begin{array}{l}\text { Trenggalek } \\
\text { Taman } \\
\text { Kili Kili } \\
\text { (TKK) }\end{array}$} & \multirow{2}{*}{$\begin{array}{l}\text { Tulungagung } \\
\text { Pathuk } \\
\text { Gebang (PG) }\end{array}$} & \multirow{2}{*}{$\begin{array}{l}\text { Malang } \\
\text { Bajulmati } \\
\text { (BM) }\end{array}$} & \multicolumn{2}{|c|}{ Jember - Banyuwangi } \\
\hline & & & & & $\begin{array}{l}\text { Sukamade } \\
\text { (TNMB) }\end{array}$ & $\begin{array}{l}\text { Ngagelan } \\
\text { (TNAP) }\end{array}$ \\
\hline $\begin{array}{l}\text { Panjang } \\
\text { pantai, diukur } \\
\text { dari batas } \\
\text { headland }(\mathrm{m})\end{array}$ & 4.586 & 6.688 & 125 & 1.440 & 3.042 & 19.140 \\
\hline $\begin{array}{l}\text { Lebar area } \\
\text { supratidal (m) }\end{array}$ & $15-35,6$ & $7,6-56,2$ & $10,0-15,5$ & $20,4-71,2$ & $34,7-75,7$ & $18,5-39,7$ \\
\hline $\begin{array}{l}\text { Kategori } \\
\text { kemiringan } \\
(\%)\end{array}$ & $\begin{array}{l}\text { Sangat } \\
\text { Landai } \\
\quad(2-5)\end{array}$ & $\begin{array}{l}\text { Sangat } \\
\text { landai } \\
\quad(2-5)\end{array}$ & $\begin{array}{l}\text { Sangat landai } \\
(2-5)\end{array}$ & $\begin{array}{l}\text { Landai } \\
\qquad(5-9)\end{array}$ & $\begin{array}{l}\text { Landai } \\
\qquad(5-9)\end{array}$ & $\begin{array}{l}\text { Landai } \\
\qquad(5-9)\end{array}$ \\
\hline $\begin{array}{l}\text { Substrat } \\
\text { dominan }\end{array}$ & $\begin{array}{l}\text { Pasir } \\
\text { sedang }\end{array}$ & $\begin{array}{l}\text { Pasir } \\
\text { sedang }\end{array}$ & Pasir kasar & $\begin{array}{l}\text { Pasir } \\
\text { sedang }\end{array}$ & $\begin{array}{l}\text { Pasir } \\
\text { sedang }\end{array}$ & $\begin{array}{l}\text { Pasir } \\
\text { sedang }\end{array}$ \\
\hline $\begin{array}{l}\text { Karakteristik } \\
\text { vegetasi }\end{array}$ & $\begin{array}{l}\text { Pandan } \\
\text { laut } \\
\text { (Pandanus } \\
\text { tectorius) }\end{array}$ & $\begin{array}{l}\text { Pandan laut } \\
\text { (Pandanus } \\
\text { tectorius) }\end{array}$ & $\begin{array}{l}\text { Pandan laut } \\
\text { (Pandanus } \\
\text { tectorius), } \\
\text { berbatasan } \\
\text { dengan hutan } \\
\text { pantai }\end{array}$ & $\begin{array}{l}\text { Pandan } \\
\text { laut } \\
\text { (Pandanus } \\
\text { tectorius) }\end{array}$ & $\begin{array}{l}\text { Pandan laut } \\
\text { (Pandanus } \\
\text { tectorius) } \\
\text { berbatasan } \\
\text { dengan } \\
\text { hutan } \\
\text { pantai }\end{array}$ & $\begin{array}{l}\text { Pandan } \\
\text { laut } \\
\text { (Pandanus } \\
\text { tectorius) } \\
\text { berbatasan } \\
\text { dengan } \\
\text { hutan } \\
\text { pantai }\end{array}$ \\
\hline $\begin{array}{l}\text { Status } \\
\text { kawasan }\end{array}$ & $\begin{array}{l}\text { Pantai } \\
\text { Wisata }\end{array}$ & $\begin{array}{l}\text { Kawasan } \\
\text { Konservasi }\end{array}$ & Belum ada & $\begin{array}{l}\text { Pantai } \\
\text { Wisata }\end{array}$ & $\begin{array}{l}\text { Taman } \\
\text { Nasional }\end{array}$ & $\begin{array}{l}\text { Taman } \\
\text { Nasional }\end{array}$ \\
\hline $\begin{array}{l}\text { Pengelola } \\
\text { kawasan }\end{array}$ & Masyarakat & Masyarakat & Masyarakat & Masyarakat & $\begin{array}{l}\text { Balai } \\
\text { Taman } \\
\text { Nasional }\end{array}$ & $\begin{array}{l}\text { Balai } \\
\text { Taman } \\
\text { Nasional }\end{array}$ \\
\hline $\begin{array}{l}\text { Aktivitas di } \\
\text { pantai }\end{array}$ & $\begin{array}{l}\text { Wisata } \\
\text { bahari dan } \\
\text { tambak }\end{array}$ & $\begin{array}{l}\text { Wisata } \\
\text { terbatas }\end{array}$ & - & $\begin{array}{l}\text { Wisata } \\
\text { bahari }\end{array}$ & - & - \\
\hline $\begin{array}{l}\text { Jenis penyu } \\
\text { ditemukan }\end{array}$ & $\begin{array}{l}\text { 2, dominan } \\
\text { L. olivacea }\end{array}$ & $\begin{array}{l}\text { 4, dominan } \\
\text { L. olivacea }\end{array}$ & C. mydas & C. mydas & $\begin{array}{l}\text { 4, dominan } \\
\text { C. mydas }\end{array}$ & $\begin{array}{l}\text { 4, dominan } \\
\text { L. olivacea }\end{array}$ \\
\hline
\end{tabular}

\section{Cuaca ekstrim di pesisir selatan Jawa 5 Tahun terakhir}

Salah satu indikasi dari perubahan iklim adalah meningkatnya frekuensi siklon. [4] mempublikasikan adanya trend peningkatan intensitas siklon tropis. Sementara itu, selama kurun waktu 5 Tahun (2014 - 2018), [5] BMKG mencatat adanya 10 siklon tropis yang terdapat di Samudera Hindia dan 6 diantaranya berdampak di area perairan selatan Jawa Timur. Peningkatan intensitas siklon menyebabkan terjadinya gelombang besar sehingga berdampak pada terbentuknya profil abrasi pada pantai peneluran. Penelusuran data sekunder dari basis data siklon JAXA [6] memperlihatkan sebaran dan intensitas siklon tropis di Samudera
Hindia pada rentang waktu 2014 - 2018 . Sepanjang tahun 2016 - 2017, terjadi peningkatan event siklon di pesisir barat Australia, yang berakibat pada gelombang tinggi di perairan selatan Jawa.

[7] mengemukakan adanya Indian Ocean Dipole (IOD) negatif yang cukup kuat pada perairan Samudera Hindia pada tahun 2016. IOD sendiri merupakan event anomali suhu permukaan laut Samudera Hindia bagian tropis, yang terjadi secara interannual (pada kurun waktu lebih dari 2 tahun). IOD berkorelasi dengan variasi SPL di Samudera Pasifik yaitu ENSO, karena adanya Sirkulasi Walker [8]. IOD positif terkait dengan fenomena El Nino, sedangkan IOD negative terkait dengan adanya La Nina. Pada Tahun 2016, IOD negatif 
mencapai puncaknya pada Bulan Juli sampai dengan September.
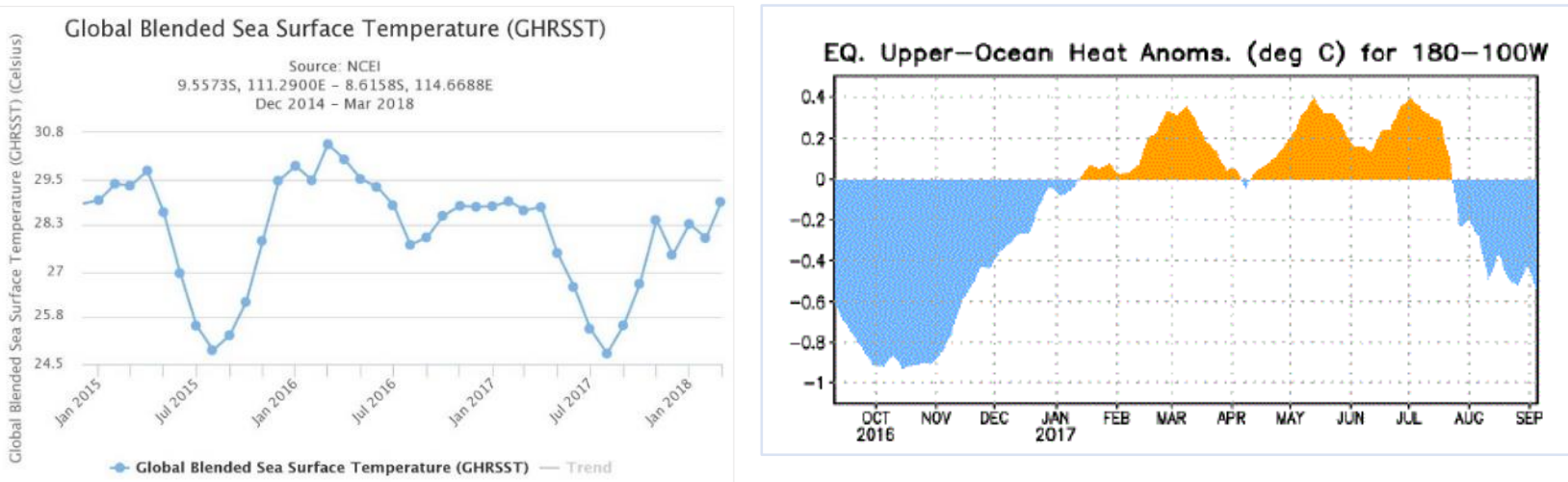

Gambar 2. Kiri: Dinamika suhu permukaan laut (SPL) pada wilayah Samudera Hindia selatan Jawa Timur periode Desember 2014 - Maret 2018 (data didapatkan dari NASA) dan Kanan: Anomali panas pada permukaan laut ekuatorial Tahun 2016 - 2017, sebagaimana grafis dari NOAA.

Pada Bulan Juni 2016, terjadi banjir pasang yang melanda pesisir selatan Jawa, sementara [9] menjelaskan mengenai adanya Siklon Cempaka pada November 2017 yang memberi dampak destruktif terhadap pesisir selatan Jawa. Adanya gelombang besar menyebabkan terjadinya perubahan garis pantai dan juga fitur abrasi yang terdapat di lokasilokasi pendaratan penyu di Selatan Jawa. [4] menjelaskan bahwa adanya badai juga menyebabkan terjadinya perendaman area di atas batas pasang surut. Apabila kondisi tersebut berlangsung secara terus menerus, maka penyu dikhawatirkan akan kehilangan area supratidal (yang berada di atas garis batas pasang surut) sebagai lokasi favorit dalam meletakkan telur.

Analisis citra temporal Landsat 8 dan Sentinel 2A menunjukkan adanya perubahan fisik pantai berupa munculnya fitur abrasi pada beberapa bagian pantai dan perubahan fisik area di sekitar mulut sungai. Adanya perubahan fisik tersebut menyebabkan pergeseran lokasi peneluran penyu, dikarenakan penyu tidak dapat naik pada pantai dengan elevasi yang curam untuk meletakkan telurnya.
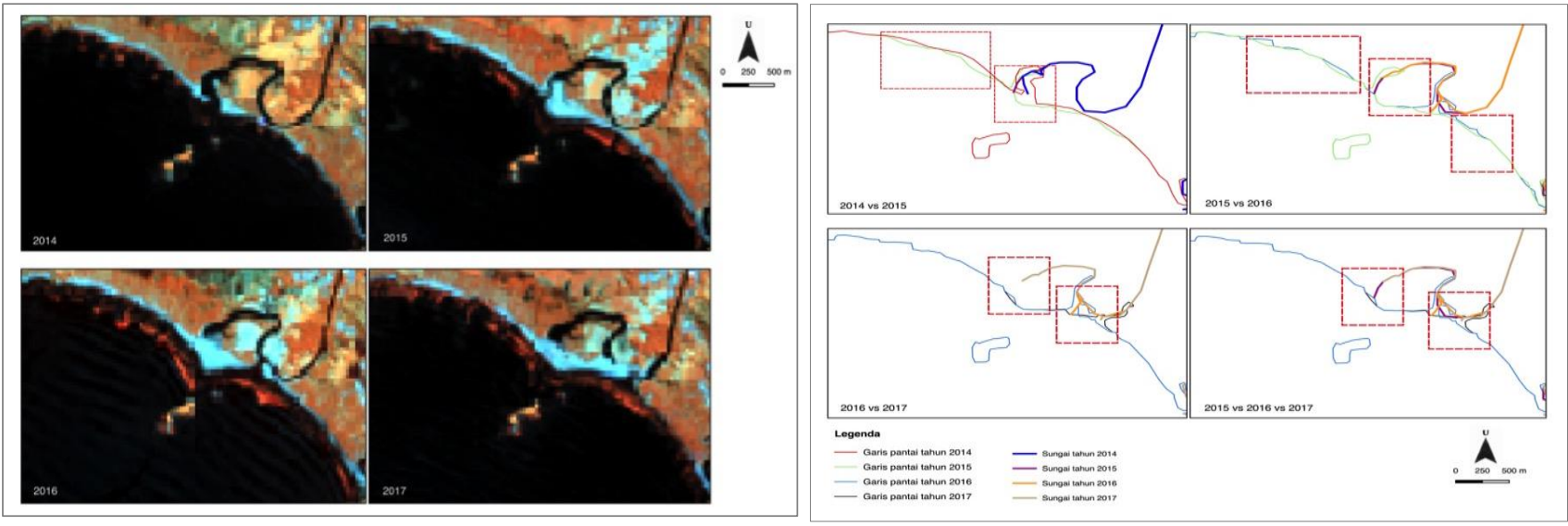

Gambar 3. Perubahan fisik pantai peneluran penyu secara temporal (2014-2017) di Pantai TKK dengan menggunakan Citra Landsat 8. Terdapat fitur abrasi dan penyempitan pada area supratidal dan perubahan bentuk muara sungai. Kondisi ini menyebabkan pergeseran area peneluran penyu di pantai tersebut. 


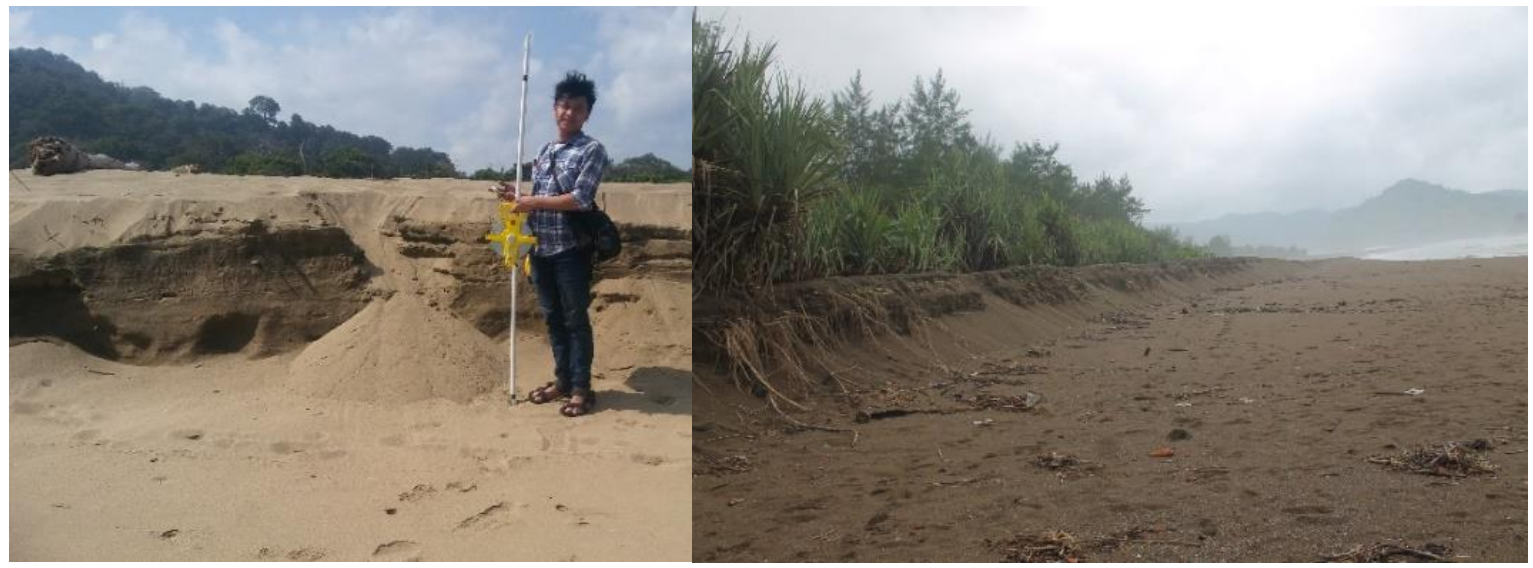

Gambar 4. Dampak cuaca ekstrim terhadap area pendaratan penyu. Munculnya fitur penebingan (kiri) pada Pantai Sukamade, TNMB dan abrasi sampai dengan batas vegetasi di Pantai TKK (kanan).

\section{Korelasi SPL dengan temperatur substrat pada pantai pendaratan penyu}

Pengolahan data dari Citra MODIS Aqua dengan resolusi $4 \mathrm{Km}$ dilakukan pada rentang Tahun 2015 - 2018 untuk mendapatkan gambaran mengenai perubahan yang terjadi pada variabel SPL pada saat musim peneluran.
Interpretasi citra satelit memperlihatkan bahwa pada Bulan Agustus Tahun 2016, suhu di perairan pesisir selatan Jawa Timur cenderung lebih hangat, dengan rata-rata berkisar antara 26 $-28^{\circ} \mathrm{C}$.
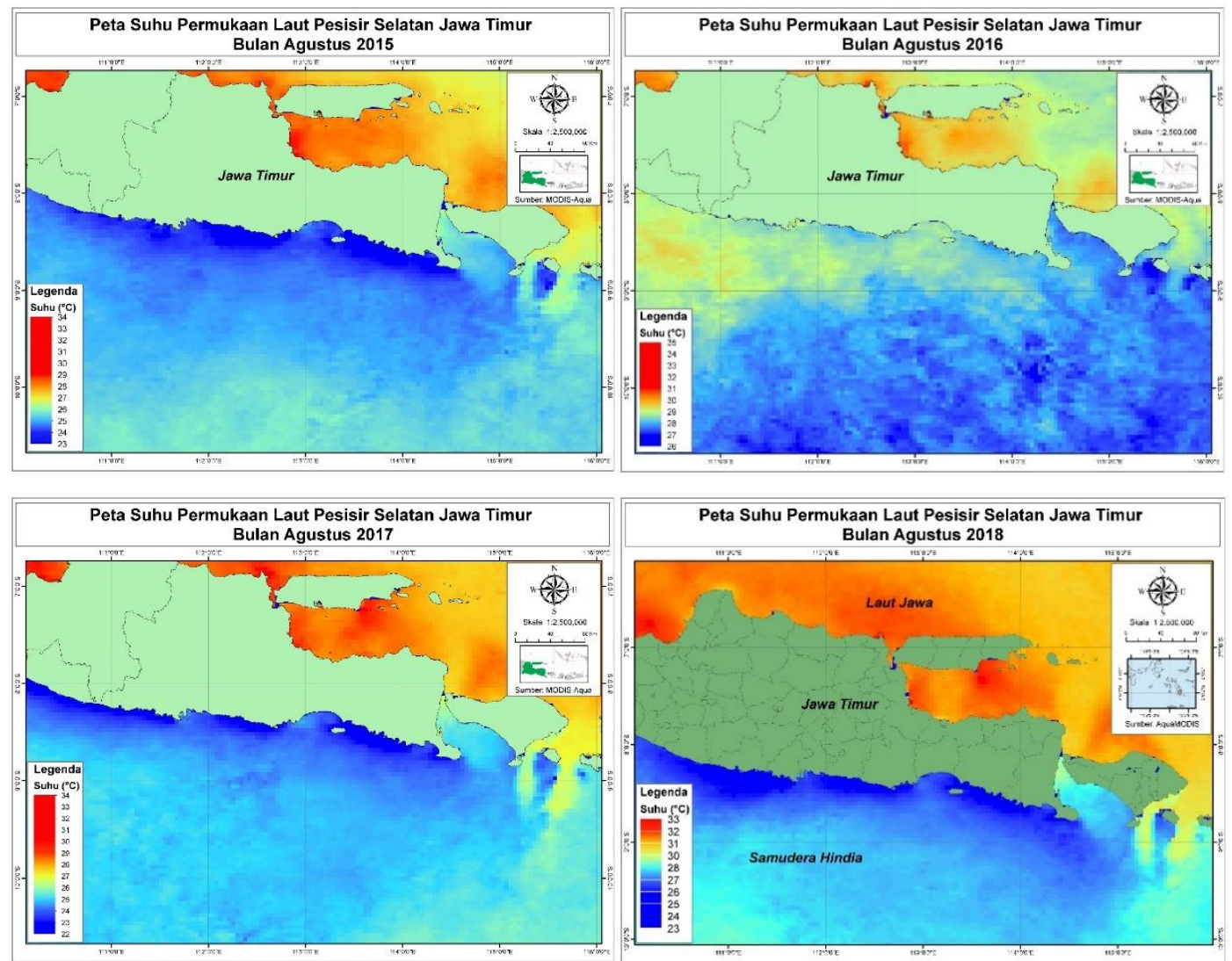

Gambar 5. Variabilitas SPL di Samudera Hindia selatan Jawa Timur pada Bulan Agustus 2015 - 2018

Sementara itu, kegiatan survei lapangan dilaksanakan pada musim yang sama, menunjukkan rentang suhu pada keenam lokasi penelitian berada pada kisaran $26,5-28,2^{\circ} \mathrm{C}$.
Ukuran butir sedimen yang dominan di area penelitian memiliki kategori pasir sedang dan pasir kasar (lihat Tabel 1), yang merupakan karakteristik khas pantai pendaratan penyu. [10] 
menyatakan bahwa proses inkubasi yang berhasil menetaskan tukik berada pada rentang temperatur substrat $25-35^{\circ} \mathrm{C}$. Kondisi kelembaban substrat pada lokasi penelitian di TKK berada pada kondisi "dry+" sampai dengan "wet + ". Kondisi tersebut mengindikasikan kelembaban pasir sarang berada pada kisaran sedang menuju tinggi. Pada lokasi wilayah timur (TNMB dan TNAP), kondisi substrat berada pada kisaran "dry+" sampai dengan "dry+ wet+"”.

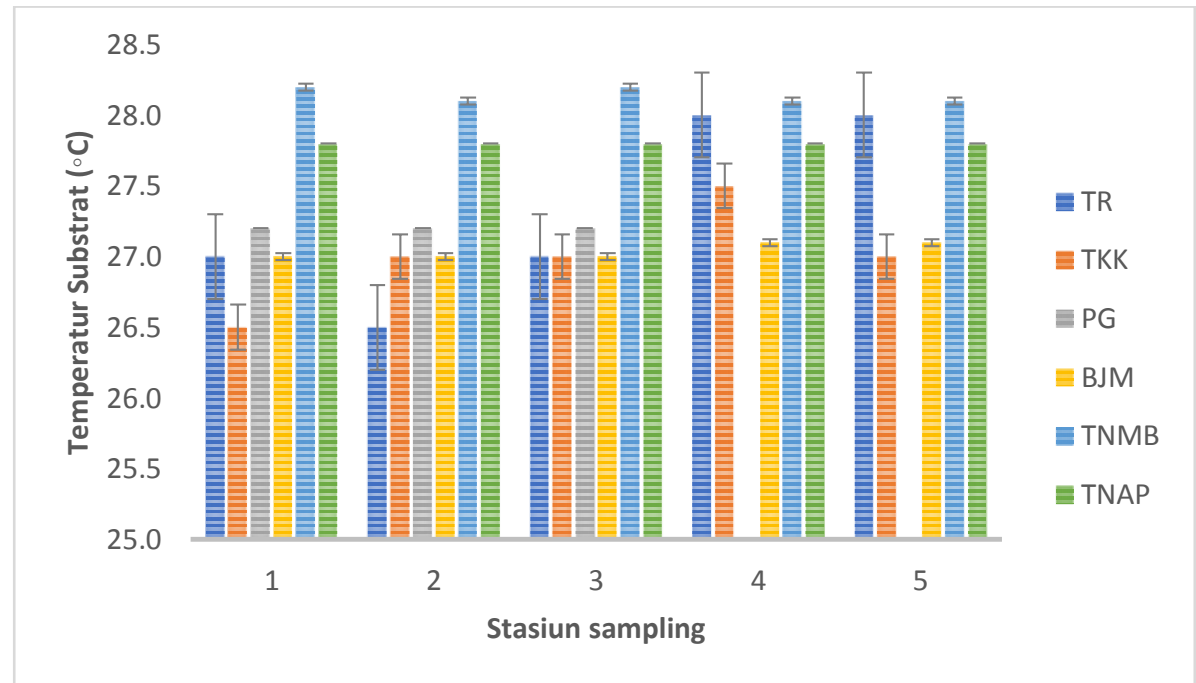

Gambar 6. Temperatur substrat pada lokasi penelitian menunjukkan rentang temperatur $26.5-28.2{ }^{\circ} \mathrm{C}$

Temperatur sarang dipengaruhi oleh warna pasir dan ukuran butir, struktur biofisik pantai, iklim lokal dan panas metabolik yang dihasilkan pada saat embrio berkembang. Mekanisme determinasi jenis kelamin menurut beberapa literatur dipengaruhi oleh regulasi aromatase, enzim yang mengonversi testosterone (hormon jantan) atau prekusor enzim tersebut menjadi estrogen (hormon betina). Pada penyu tempayan di California, temperatur yang lebih hangat $\left(>29.2^{\circ} \mathrm{C}\right)$ memproduksi lebih banyak jumlah betina, sedangkan temperatur yang lebih dingin $\left(<29.2^{\circ} \mathrm{C}\right)$ menghasilkan lebih banyak tukik jantan. Temperatur konstan yang berada pada kisaran $<29.2^{\circ} \mathrm{C}$ memproduksi jumlah tukik dengan proporsi jenis kelamin seimbang, hal ini dinamakan temperatur pivot. Variabel krusial yang mempengaruhi keberhasilan penetasan telur dan jenis kelamin adalah temperatur dan kelembaban substrat. Ketiadaan basis data yang baik menjadi kendala untuk mendapatkan gambaran yang terjadi pada lokasi-lokasi peneluran di pesisir selatan Jawa Timur secara temporal.

\section{Tantangan pengelolaan habitat konservasi penyu di pesisir selatan Jawa Timur}

Bagian paling utama dari kegiatan konservasi penyu adalah penyelamatan telur dan induk yang mendarat, dilanjutkan dengan upaya penetasan. Pada saat ini, ketersediaan data telur yang baik hanya terdapat pada 4 lokasi, yaitu TKK, BM, TMNB dan TNAP. Pada lokasi yang lain yaitu TR dan PG, terdapat kendala yang dihadapi oleh pengelola dalam rekapitulasi data telur penyu. Pada Pantai TR, kendala berupa ketiadaan petugas yang memadai, sementara untuk pantai PG, akses lokasi menjadi kendala tersendiri mengingat posisi pantai berada pada kawasan hutan alami yang jauh dari pemukiman. Data rekapitulasi telur per bulan pada saat penelitian berlangsung disajikan pada Gambar 7. 


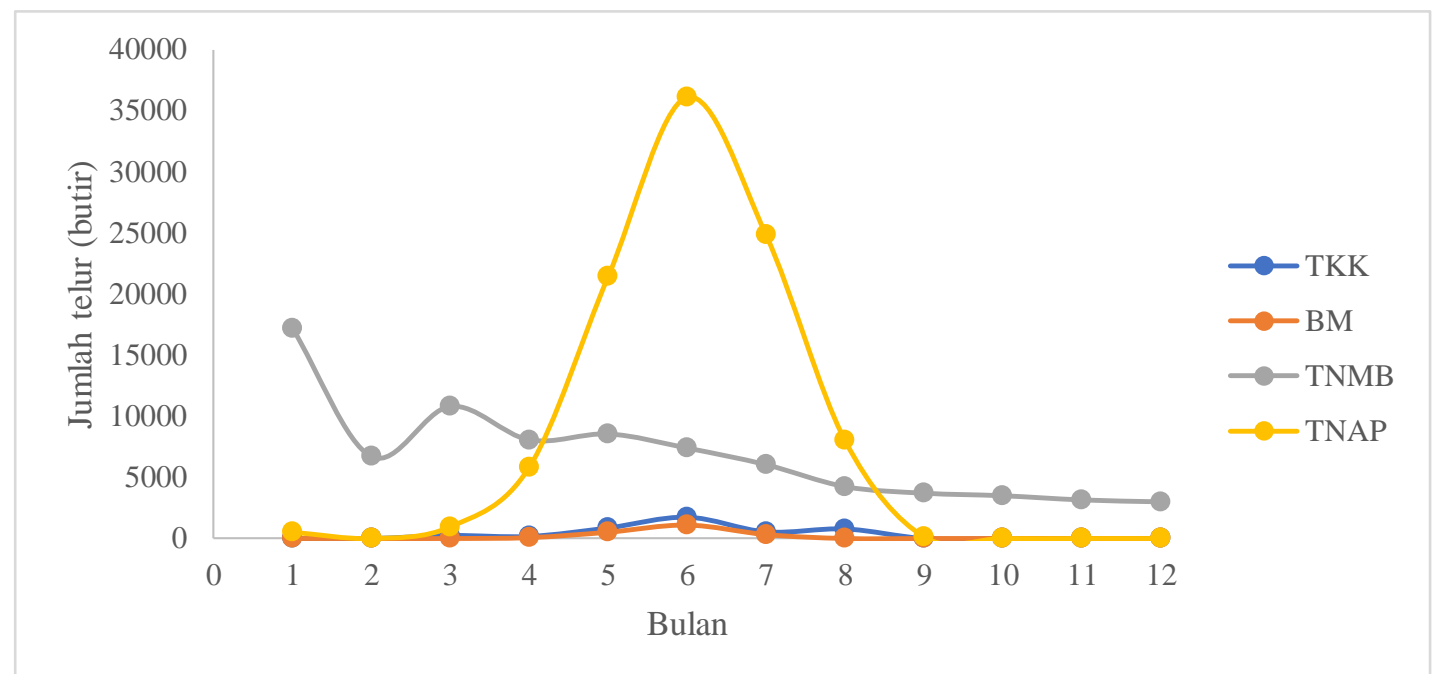

Gambar 7. Rekapitulasi jumlah telur pada 4 lokasi penelitian. 2 lokasi yang lain belum memiliki pencatatan mengenai jumlah telur dan jumlah pendaratan

Pada area di luar Taman Nasional, kegiatan penyelamatan telur melalui sarang semi alami terdapat di TR, TKK dan BM. Keberadaan sarang semi alami dapat membantu memperbaiki presentasi tukik yang menetas. Pada penelitian ini, kegiatan observasi lapangan dan penelusuran pustaka menunjukkan, dinamika jumlah penyu yang naik ke pantai pendaratan untuk bertelur bukan hanya dipengaruhi oleh faktor iklim saja. Ancaman serius yang dihadapi oleh pengelola kawasan konservasi penyu di pesisir selatan Jawa Timur lebih dominan disebabkan oleh faktor antropik, terutama pada Kawasan-kawasan konservasi yang dikelola oleh masyarakat. Beberapa kondisi yang dapat meningkatkan kerentanan berasal dari faktor internal, diantaranya: kurangnya tenaga monitoring dan keterbatasan dana untuk pengelolaan kawasan.

Faktor eksternal yang menjadi tantangan kawasan pendaratan penyu yang dikelola oleh masyarakat adalah rencana pengembangan kawasan, status lahan dan aktivitas manusia di sekitar kawasan konservasi, khususnya kegiatan wisata, pembangunan fisik dan polusi cahaya (lampu kapal, pemukiman maupun keramba pencari benih lobster). Hal yang perlu dicermati dari kegiatan pengelolaan kawasan konservasi penyu baik di Taman Nasional maupun kawasan yang dikelola oleh masyarakat, belum memiliki rencana pengelolaan sebagai upaya mengurangi risiko akibat perubahan iklim. Hal tersebut dimungkinkan oleh kejadian cuaca ekstrem yang jarang terjadi.

Walaupun pada rentang waktu 2016 2018 terdapat gelombang tinggi sepanjang tahun, yang mengakibatkan terjadinya abrasi di beberapa titik pantai yang mereka kelola, hal tersebut dianggap belum menjadi ancaman serius bagi penyu yang mendarat pada area peneluran. Upaya pengelolaan adaptif merupakan hal yang penting mengingat ancaman perubahan iklim (terutama cuaca ekstrem dan kenaikan muka air laut) pada lokasi peneluran akan semakin intens.

Sebagaimana model yang dibuat oleh [2] menunjukkan beberapa kawasan di Samudera Hindia bagian utara dan timur mengalami kenaikan muka air laut, termasuk diantaranya perairan selatan Sumatera dan Jawa.

\section{KESIMPULAN}

Dampak dari cuaca ekstrem 2016 - 2017 adalah terbentuknya beberapa fitur abrasi dan pergeseran area peneluran penyu. Walaupun begitu, perubahan iklim bukanlah satu-satunya ancaman kegiatan konservasi penyu. Tantangan terbesar berada pada aspek pengelolaan, terutama aktivitas manusia di sekitar area pendaratan penyu di Jawa Timur.

\section{UCAPAN TERIMA KASIH}

Penelitian ini didanai oleh HPP Universitas Brawijaya Tahun 2017 dan DIPA No. 042.01.2.400919/2018 Tahun 2018. Tim peneliti mengucapkan terima kasih atas support dari kelompok konservasi penyu dan Balai Taman Nasional. 


\section{DAFTAR PUSTAKA}

[1] Nuitja, I. and J.D. Lazell. J.1982. "Marine turtle nesting in Indonesia". Copeia, JSTOR. Retrieved from https://www.jstor.org/stable/1444676

[2] Han, W., Meehl, G. A., Rajagopalan, B., Fasullo, J. T., Hu, A., Lin, J., ... Yeager, S. (2010). "Patterns of Indian Ocean sea-level change in a warming climate". Nature Geoscience, 3(8), 546-550. https://doi.org/10.1038/ngeo901

[3] Fuentes, M. M, P. B., Limpus, C. J., \& Hamann, M. 2011. "Vulnerability of sea turtle nesting grounds to climate change". Global Change Biology, 17(1), 140-153. https://doi.org/10.1111/j.13652486.2010.02192.x

[4] Webster, P. J., G. J. Holland, J. A., Curry, \& H.-R. Chang. "Changes in Tropical Cyclone Number, Duration, and Intensity in a Warming Environment". Science, 309(5742),1844-1846.

https://doi.org/10.1126/science.1116448, 2005.
[5] BMKG. "Tropical Cyclone Warning Center (TCWC)". http://meteo.bmkg.go.id/

[6] JAXA Tropical Cyclone Database. http://sharaku.eorc.jaxa.jp

[7] Lim, E.-P., \& H. H. Hendon. "Causes and Predictability of the Negative Indian Ocean Dipole and Its Impact on La Niña During 2016". Scientific Reports, 7(1), 12619. https://doi.org/10.1038/s41598-017-12674z, 2017.

[8] Shinoda, T., H. H. Hendon, \& M. A. Alexander. "Surface and subsurface dipole variability in the Indian Ocean and its relation with ENSO". Deep Sea Research Part I: Oceanographic Research Papers, 51(5),619-635, 2004.https://doi.org/10.1016/J.DSR.2004.0 1.005

[9] Swarinoto, Y., A. Putra, E. Fibriantika, \& N. Alfuadi. 2019. "Atmospheric Dynamics Analysis of Tropical Cyclone Cempaka". IJSBAR

[10] Hawkes, L., A. C. Broderick, M. H. Godfrey, \& B. J. Godley. "Climate Change And Marine Turtles". Endangered Species Research Vol. 7: 137-154, 2009. doi: 10.3354/esr00198 